3 Johnston CC, Lavy N, Lord T, et al. Osteopetrosis. A clinical, genetic, metabolic and morphologic study of the dominantly inherited benign form. Medicine 1968;47:149-67.

$4 \mathrm{Kahn}$ AJ, Raisz LG. Use of marrow transplantation in congenital osteopetrosis: a progress report. Metab Bone Dis Relat Res 1981;3:78-9.

5 Marks SC, Walker DG. Mammalian osteopetrosis-a model for studying cellular and humeral factors in bone resorption. In: Bourne GH, ed. The biochemistry and physiology of bone. New York: Academic Pres Inc, 1976:227-301.

6 Horan FT, Beighton PH. Infantile metaphyseal dysplasia or "battered babies"? Y Bone foint Surg $[B r]$ 1980;62:243-7.

7 Reeves JD, August CS, Humbert JR, Weston WL. Host defense in infantile osteopetrosis. Pediatrics 1979;64:202-6.

8 Walker DG. Control of bone resorption by hematopoietic tissue. The induction and reversal of congenital osteopetrosis in mice through the use of bone marrow and splenic transplants. $\mathcal{F}$ Exp Med 1975;142:651-63.

9 Loutit JF, Sansom JM, Osteopetrosis of microphthalmic mice-a defect of haematopoietic stem cell? Calcified Tissue Research 1976;20:251-9.

10 Nisbet NW, Menage J, Loutit JF. Resolution and relapse of osteopetrosis in mice transplanted with myeloid tissue of variable histocompatibility. Transplantation 1979;28:285-90.

11 Ballet JJ, Griscelli C. Lymphoid cell transplantation in human osteopetrosis. In: Horton JE, Tarpley TM, Davis WF, eds. Mechanisms of localized bone loss. Washington DC: Information Retrieval Inc, 1978:399-414.

12 Nisbet NW. Bone absorption and the immune system. Scand I Immunol 1981;14:599-605.

13 Nisbet NW, Waldron SF, Marshall MJ. Failure of thymic grafts to stimulate resorption of bone in the Fatty/Orl-op rat. Calcif Tissue Int 1983;35:122-5.

14 Sorell M, Kapoor N, Kirkpatrick D, et al. Marrow transplantation for juvenile osteopetrosis. Am f Med 1981;70:1280-7.

15 Coccia PF, Krivit W, Cerrenka J, et al. Successful bone marrow transplantation for infantile malignant osteopetrosis. N Engl I Med 1980;302:701-8.

16 Sieff CA, Levinsky RJ, Rogers DW, et al. Allogeneic bone marrow transplantation in infantile malignant osteopetrosis. Lancet 1983;ii:437-41.

17 Coccia PF. Cells that resorb bone. N Engl f Med 1984;310:456-8.

18 Marks SC. Congenital osteopetrotic mutants as probes of origin, structure and function of osteoclasts. Clin Orthop 1984;189:239-63.

19 Parkman $R$. The application of bone marrow transplantation to the treatment of genetic diseases. Science 1986;232:1373-8.

20 Marshall MJ, Rees JA, Nisbet NW, Wiseman J. Reduced life span of the osteoclast in osteopetrotic (mi/midi) mice. International fournal of Bone and Mineral Research (in press).

\section{Should general practitioners be able to prescribe orthopaedic appliances?}

Why should general practitioners not be allowed to order lumbosacral corsets for their patients with backache when they can prescribe drugs which may be both expensive and dangerous?

In the days when tuberculosis and poliomyelitis were common orthopaedic surgeons became expert in making and fitting various appliances used to support the halt and the lame. In many cases they set up special workshops in their hospitals to supply this need. When the National Health Service was introduced in 1948 it may well have seemed natural that hospitals should be the source of the appliances to be provided for patients. During the next 10 years orthopaedic practice altered as social changes and the Salk vaccine reduced, and almost eliminated, these two diseases. The need for calipers and braces diminished; but an increasing number of patients with backache came to orthopaedic clinics. The demand for simple back supports also increased, and these were mostly prescribed by orthopaedic surgeons. In more recent years rheumatologists have undertaken a share of this work. A new specialty of orthotics and prosthetics has now developed to prescribe and make more complicated appliances and artificial limbs.

So what is special about the ordering of corsets that it cannot be done by general practitioners? Or can they getz round the regulations which state: "A hospital may order and provide an appliance for a patient only if the patient has been ${ }^{c}$ examined and the appliance prescribed by or under the $\rho$ direction of a consultant, either at a hospital or clinic, or on the occasion of a domiciliary visit."

An inquiry to orthopaedic surgeons throughout England, m Scotland, and Northern Ireland suggests that the rules are? not being broken: in no area are general practitioners $\overrightarrow{\vec{*}}$ ordering corsets. Most of those questioned thought that general practitioners should be allowed to do so, but theres were some reservations. The cost of a custom made corset is $\bar{s}$. $£ 50-£ 60$, and there was concern about the possibility of overprescription; but this is largely a matter of education. Orthopaedic surgery and rheumatology are squeezed into $a$ small corner of the curriculum in many medical schools, so $a^{\circ}$ student may never be taught about corsets. It would take $a \vec{\omega}$ long time to correct this failing, but surely a postgraduate $\frac{\rho}{\circ}$ seminar lasting a day or half a day would be a remedy.

All this is written on the assumption that a corset is usefuitio in relieving backache. Many doctors believe this to be true. Certainly a multicentre study on the treatment of low back pain concluded that a "corset was as effective as the other. treatments, and it is certainly less expensive than manipulation or physiotherapy and safer than drugs."' This waso written in 1975, and no new miracle cure for backache has o been found since then.

I am heartened to learn that open access to orthopaedico' appliances (mainly corsets and collars) now exists in Clwyd? (p 000). A clinic is run by a nursing sister from orthopaedic outpatients and was begun as a local response to the Duthie $\vec{\circ}$ report, which encouraged such an arrangement in an attempto to reduce pressure on consultant orthopaedic clinics. ${ }^{3}$ The Clwyd venture has been successful, since the average waiting time for an orthopaedic appointment was 5 to 6 months (regrettably this is not uncommon in Britain) and mosto patients were seen in the appliance clinic within five weeks of $\stackrel{0}{\Phi}$ referral.

The matter could be dealt with centrally by putting corsets on the drug tariff, which is not as odd as it might seem since the tariff now includes trusses and elastic stockings. But this might well take a long time, and a lot of argument, before it could be achieved. Clearly it is open for local groups of interested doctors to get together to make the arrangementso that answer the needs in their own area. What can be done in north Wales can be done elsewhere. Why wait?

Professor Emeritus of Orthopaedic and Accident Surgery,

Wadenhoe,

Nr Oundle,

Peterborough PE8 5ST

1 Department of Health and Social Security. Provision of medical and surgical appliances and orthopaedic footwear to NHS patients. London: HMSO, 1981. (Booklet MHMSO.)

2 Doran DML, Newell DJ. Manipulation in the treatment of low back pain: a multicentre study@O BrMed F 1975; ii: 161-4.

3 Department of Health and Social Security. Orthopaedic services: waiting times for outpatientes appointments and inpatient treatment. Report of a working party. London: HMSO, 1981. 